\title{
PECULIAR FEATURES OF AORTIC WALL STRUCTURE AMONG CHILDREN WITH COARCTATION
}

DOI: 10.36740/WLek202004132

\author{
Daria S. Khapchenkova', Ganna S. Senatorova² \\ 'DONETSK NATIONAL MEDICAL UNIVERSITY, LYMAN, UKRAINE \\ ${ }^{2}$ KHARKIV NATIONAL MEDICAL UNIVERSITY, KHARKIV, UKRAINE
}

\begin{abstract}
The aim of the study to evaluate the peculiarities of the aortic wall structure at the place of coarctation.

Materials and methods: Studying of the aortic sections removed during operative correction at the place of constriction. 10 children at the age between 1 to 6 months were undergone the operation. Intraoperative aortic biopsy specimens were observed in $10 \%$ neutral formalin. Histologic sections were prepared in a conventional way followed by staining them with hematoxylin-eosin.

Results: Histological examination in the areas of constriction revealed that the endothelium in all the preparations had poor expressiveness. The most significant changes were recorded in the middle layer of the aorta in the form of reduced development of elastic fibers, their fragmentation and chaotic arrangement. Angiomatosis with the formation of thin-layer small vessels by capillary type was found out. In all the preparations, areas of emptying of cells and fibers of the middle cover with the formation of cystic structures were revealed.

Conclusions: The histological examination has revealed changes in the structure of the aorta wall, which may indicate the systemic nature of the lesion and make it possible to consider coarctation of the aorta to be a manifestation of systemic vasculopathy. The above-mentioned facts determine the need for a more detailed examination of children with the specified pathology at different stages of observation.
\end{abstract}

KEY WORDS: coarctation, children, histological examination, wall structure

Wiad Lek. 2020;73(4):789-791

\section{INTRODUCTION}

Coarctation of the aorta (CoA) is a defect characterized by stenosis of the aorta at some interval of the vessel [1]. CoA is one of the most common cardiac and vascular abnormalities [2]. Significant experience of diagnostics and treatment, invention of various methods of surgical intervention do not allow to solve the question about the causes of development of complications in the remote postoperative period definitely [3]. This category of patients has functional and macroanatomical disorders, special histological structure of the wall not only of the aorta [4], but also structural and morphological changes of other vessels of the large blood circulation $[5,6]$. The complex of these causes leads to cardiovascular and cerebrovascular catastrophes, which reduces the quality and life expectancy of patients who suffer from aortic coarctation [7].

Making a conclusion, coarctation of the aorta can be described as a manifestation of connective tissue dysplasia, a variant of systemic vasculopathy. This, in turn, requires a more detailed examination of patients before surgery and observation of this group of patients in the postoperative period.

\section{THE AIM}

To determine the peculiar features of the aortic wall structure in the coarctation area.

\section{MATERIALS AND METHODS}

Surgical correction of aortic defect was performed on 10 children aged from 1 to 6 months. During surgery for coarctation of the aorta, areas of the vessel constriction were removed. Intraoperative biopsies were fixed in 10\% neutral formalin solution, histological sections were made after normal posting, followed by hematoxylin-eosin staining. Microscopy was performed using a software-microscopic complex that included an Olympus CX 31 light microscope and an Olympus LC 20 digital video camera.

The work is performed on the Kharkiv Regional Clinical Children's Hospital.

The Committee on Ethics and Bioethics of KhNMU does not dispute the histological examination of intraoperative biopsies. Parents agreed to the study.

\section{RESULTS AND DISCUSSION}

Histological examination of the coarctation area of the aortic wall showed that the architectonics was broken in all the fragments. The endothelium had poor expression in all the preparations.

The most significant changes were diagnosed in the middle layer of the aorta wall, namely: elastic fibers are expressed weakly, they are fragmented, with disordered 


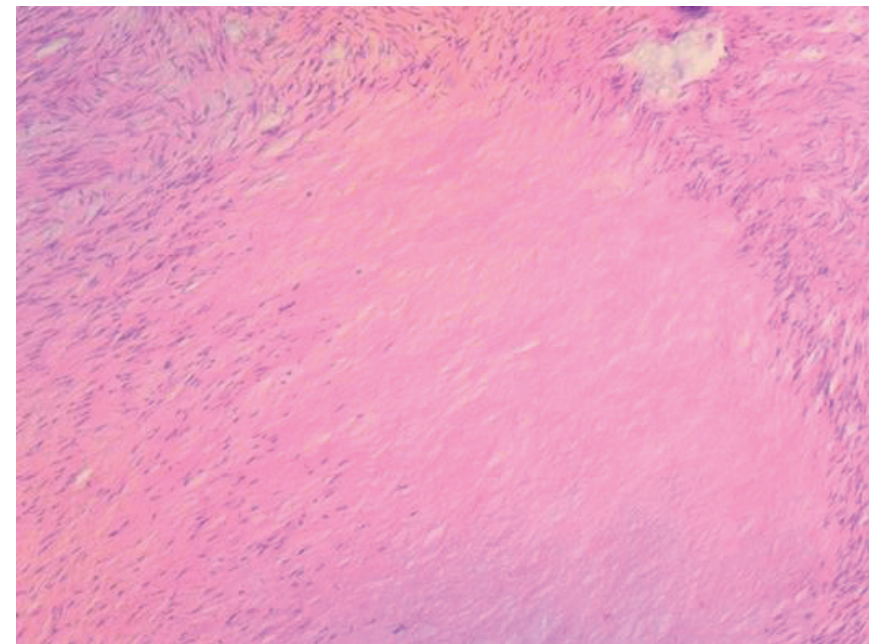

Fig. 1. Large, homogeneous cell-free areas. Coloring with hematoxylineosin. Increase x 40 .

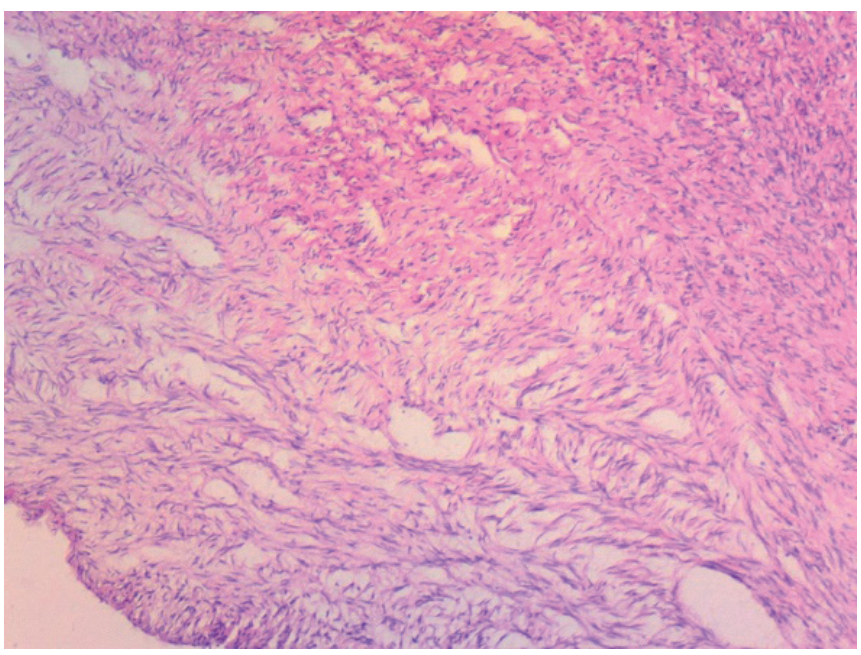

Fig. 3. Newly formed vessels with spindle cell myocytes around. Coloring with hematoxylin-eosin. Increase x 40.

location, there are large homogeneous cell-free areas - foci of necrosis of smooth muscle cells, collagen fibers and malasthes (Fig. 1).

Accumulation of mast cells in the form of spindle cells and epithelioid cells was observed around these areas. The location of such clusters is uneven in different parts of the aortic wall, chaotic (Fig. 2).

Angiomatosis with the formation of thin-walled small vessels according to the capillary type was found out. Around the vessels the number of spindle cell and epithelioid myocytes increased (Fig. 3).

In all the preparations, the areas of the cell and fibers of the middle layer with the formation of cystic structures were revealed (Fig. 4). Edema, thinning of all layers of the aorta were found out in all the fragments, three of seven preparations revealed hypoelastosis and areas of anelastosis.

The outer lining of the aorta was characterized by a cluster of newly formed vessels that were located among loose connective tissue.

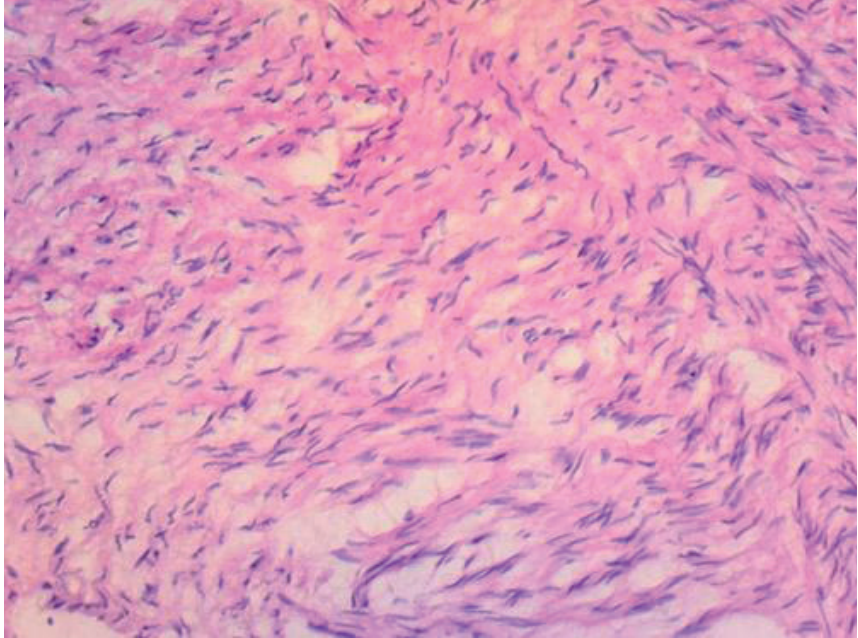

Fig. 2. Chaotic cells and epithelioid myocytes with chaotic location. Coloring with hematoxylin-eosin. Increase x 100.

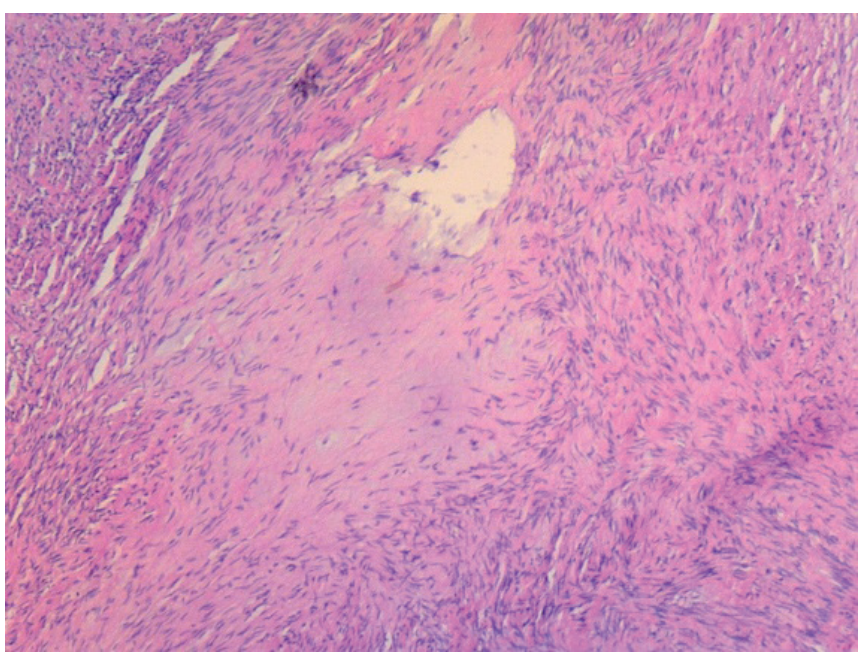

Fig. 4. In the area of coarctation, the destruction of cells and fibers is observed. Coloring with hematoxylin-eosin. Increase x 40.

The aorta is a vessel of elastic type that provides a uniform passage of the pulse wave. Changes in its elastic-collagen scaffold lead to vascular dysfunction and, as a consequence, may provoke various postoperative complications [8]. The morphological changes of the wall of different parts of the aorta and brachiocephalic vessels make it possible to consider this pathology a systemic vascular problem $[4,5]$. We understand that histological research is rather simple for the modern period of technology development, but unfortunately, not all the health care institutions, at the times of economic instability, can afford more modern and effective research. Therefore, histological examination of intraoperative sections of the aorta is the first stage of scientific study of the peculiar features of the vessel wall structure.

\section{CONCLUSIONS}

1. Coarctation of the aorta as a systemic vasculopathy leads to morphological changes of the walls of the vessels in the form of: 
- poor expression of the endothelium;

- significant changes in the middle layer of the aorta (decrease in the volume of elastic fibers, their fragmented and chaotic location, formation of areas of smooth muscle cell necrosis in the form of spindle cell and epithelioid myocytes);

- angiomatosis with the formation of thin-walled small vessels of capillary type around the aorta;

- the emergence of zones of destruction of cells and fibers of the middle layer with the formation of cystic structures.

2. Taking into consideration the nature of morphological changes in aortic coarctation, early diagnosis and surgical treatment should be supplemented by continuous observation of patients in the postoperative period because of the possibility of deepening the pathological condition.

\section{PROSPECTS FOR FURTHER RESEARCH}

For all the patients, the result of surgical treatment was considered satisfactory. Children were discharged under the supervision of a pediatric cardiologist at the place of residence. Taking into consideration the knowledge of the features of the aortic wall structure of this category of patients, it will be of particular interest to monitor them in the remote postoperative period, given the data obtained - the possibility of predicting the development of complications or other pathological conditions in the future of the cardiovascular system in patients in this cohort.

\section{REFERENCES}

1. Bokerija L.A., Gudkova R.G. Serdechno-sosudistaja hirurgija - 2014 [Cardiovascular surgery - 2014]. Moscow: Nauchnyj centr serdechnososudistoj hirurgii im. A.N. Bakuleva. 2015;226 (in Russian).

2. Sojnov I.A., Sinel'nikov Ju.S., Gorbatyh A.V. i dr. Arterial'naja gipertenzija u pacientov posle korrekcii koarktacii i gipoplazii dugi aorty [Arterial hypertension in patients after correction of coarctation and hypoplasia of the arch of the aorta]. Circulation Pathology and Cardiac Surgery. 2015;19,2:102-112. (in Russian).

3. O'Sullivan J.J., Derrick G., Darnell R. Prevalence of hypertension in children after early repair of coarctation of the aorta: a cohort study using casual and 24 hour blood pressure measurement. Heart. 2002;88:163-166.

4. Todorov S.S. Kletochno-mezhkletochnye vzaimootnoshenija v razlichnyh otdelah aorty posle rekonstruktivnyh operacij pri koarktacii u detej pervogo goda zhizni [Cellular/intercellular interrelations in various parts of aorta after reconstructive treatment of aortic stenosis in infants]. Circulation Pathology and Cardiac Surgery. 2017;21(2):52-59. doi. org/10.21688/1681-3472-20172-52-59. (in Russian).
5. Sojnov I.A., Sinel'nikov Ju.S., Kliver E.Je. Morfologicheskie osobennosti brahiocefal'nyh arterij u pacientov s gipoplaziej dugi aorty [Morphological features of brachiocephalic arteries in patients with aortic arch hypoplasia]. Circulation Pathology and Cardiac Surgery. 2015; 4:14-18. (in Russian).

6. Suhareva G. Je. Vzaimosvjaz' koarktacii aorty u detej s sochetannoj patologiej sosudov shei i golovy [Interrelation of aortic coarctation in children with combined pathology of the neck and head vessels]. Experimental and Clinical Medicine. 2008; 4:71-74.

7. Toro-Salazar 0.H., Steinberger J., Thomas W. et al. Long-term follow-up of patients after coarctation of the aorta repair. Am. J. Cardiol. 2002; 89:541-547.

8. Gorbatyh Ju.N., Sinel'nikov Ju.S., Sojnov I.A. i dr. Hirurgicheskaja korrekcija anomalij dugi aorty u mladencev v uslovijah iskusstvennogo krovoobrashhenija [Surgical correction of coarctation of the aorta with distal aortic arch hypoplasia in infants]. Surgery. 2015; 8:18-21. doi: 10.17116/hirurgia2015818-21 (in Russian).

The study is a part of the comprehensive research work of the Kharkiv National Medical University of the Ministry of Health of Ukraine "Stratification of cardiovascular risk factors in the pediatric population of Kharkiv region" (state registration number 0118U000925). The author is the direct executor of the part of these studies.

ORCID and contributionship:

Daria S. Khapchenkova - 0000-0002-5965-9905 A,B,C,D

Ganna S. Senatorova - 0000-0001-6725-4695 E,F

Conflicts of interest:

Authors declare no conflict of interest.

\section{CORRESPONDING AUTHOR \\ Daria S. Khapchenkova \\ Department of Human Anatomy, \\ Donetsk National Medical University, Lyman, Ukraine \\ tel: +380509281337 \\ e-mail:xapcha86@gmail.com}

Received: 26.07.2019

Accepted: 15.02 .2020

\footnotetext{
A - Work concept and design, B - Data collection and analysis, C - Responsibility for statistical analysis, D-Writing the article, $\mathbf{E}$-Critical review, $\mathbf{F}$ - Final approval of the article
} 